University of Nebraska - Lincoln

DigitalCommons@University of Nebraska - Lincoln

2018

Long-term monitoring of Scripps's Murrelet and Guadalupe

Murrelet at San Clemente Island, California: evaluation of baseline data in 2012-2016

Darrell L. Whitworth

Harry R. Carter

Michael W. Parker

Franklin Gress

Melissa Booker

Follow this and additional works at: https://digitalcommons.unl.edu/usnavyresearch

This Article is brought to you for free and open access by the U.S. Department of Defense at

DigitalCommons@University of Nebraska - Lincoln. It has been accepted for inclusion in U.S. Navy Research by an authorized administrator of DigitalCommons@University of Nebraska - Lincoln. 


\title{
Long-term monitoring of Scripps's Murrelet and Guadalupe Murrelet at San Clemente Island, California: evaluation of baseline data in 2012-2016
}

\author{
Darrell L. Whitworth ${ }^{1, *}$, Harky R. Carter $1, \dagger$, Michael W. Parker ${ }^{1}$, \\ Franklin Gress ${ }^{1}$, AND Melissa BoOKer ${ }^{2}$ \\ ${ }^{1}$ California Institute of Environmental Studies, Box 1185, Davis, CA 95617 \\ ${ }^{2}$ Department of the Navy, Environmental Division, N-45, Naval Base Coronado \\ PWO Bldg. \#3, Box 357088, San Diego, CA 92135
}

\begin{abstract}
San Clemente Island (SCI) supports one of the smallest Scripps's Murrelet (Synthliboramphus scrippsi; SCMU) colonies in the world, and perhaps the only colony of Guadalupe Murrelets (S. hypoleucus; GUMU) in California. In 2012-2016, the U.S. Navy sponsored development of a long-term murrelet monitoring program at SCI that utilized nocturnal spotlight surveys, night-lighting at-sea captures, and nest monitoring. Standardized spotlight survey transects were established in nearshore waters off breeding areas at Seal Cove and southeast SCI (SESCI). Baseline mean spotlight counts were $29 \pm 15$ murrelets $(n=31)$ at Seal Cove in 2013-2016 and $21 \pm 10$ murrelets $(n=15)$ at SESCI in 2014-2016. We banded 201 SCMU captured in congregations at Seal Cove $(n=158)$ and SESCI $(n=43) ; 12 \%$ of the SCMU from Seal Cove and 7\% from SESCI were recaptured $\geq 1$ year after banding. We also banded 21 GUMU at Seal Cove, but none were recaptured. Murrelet nests or eggs were found in 6 shoreline breeding "refuges" at Seal Cove and SESCI that were seldom if ever visited by island foxes (Urocyon littoralis clementae) and feral cats (Felis catus). Incubating SCMU were observed in 4 nest sites, but in 8 other sites only eggs or eggshells were found. Overall hatching success was very low $(12 \% ; n=17$ clutches) in 2012-2016, apparently due to intraspecific competition for limited nest crevices at Seal Cove and predation (or possibly abandonment and subsequent egg scavenging) by foxes or black rats (Rattus rattus) at SESCI. Using spotlight survey data, we estimated 115 murrelet pairs (range 79-208) at SCI, including 110 pairs (range 76-199) of SCMU and 5 pairs (range 3-9) of GUMU, although a GUMU nest has not yet been found. Power analyses of Seal Cove spotlight data indicated that surveys conducted over 9 nights per year for 20 years could reliably (power $\geq 0.90$ ) detect minimum population changes of $\pm 1.7 \%$ per annum. Additional efforts are needed to (1) confirm the breeding status of GUMU; (2) investigate alternative methods of rat control to increase hatching success in murrelet breeding refuges; and (3) enhance breeding habitats to reduce intraspecific competition for nest sites and increase the number of monitored nests.
\end{abstract}

Resumen.-La isla San Clemente (SCI, por sus siglas en inglés) aloja a una de las colonias de mérgulos de Scripps (Synthliboramphus scrippsi; SCMU) más pequeñas del mundo, y tal vez la única colonia de mérgulos californianos aliclaros (S. hypoleucus; GUMU) en California. Entre los años 2012-2016, la Marina de los EE.UU. patrocinó el desarrollo de un programa a largo plazo de monitoreo de mérgulos en la Isla San Clemente, apoyándose de muestreos nocturnos, capturas en el mar mediante iluminación y monitoreo de nidos. Se establecieron muestreos en transectos estandarizados en zonas cercanas a la costa, fuera de las áreas de crianza, en Seal Cove y el sudeste de la Isla San Clemente (SESCI, por sus siglas en inglés). El número promedio fue de $29 \pm 15$ mérgulos $(n=31)$ en Seal Cove entre 2013-2016, y de $21 \pm 10$ mérgulos $(n=15)$ en SESCI entre 2014-2016. Anillamos 201 mérgulos de Scripps que fueron capturados en grupos en Seal Cove $(n=158)$ y SESCI $(n=43)$, el $12 \%$ de los mérgulos de Seal Cove y el $7 \%$ de los de SESCI fueron recapturados $\geq 1$ año después de haber sido anillados. Así mismo, anillamos 21 mérgulos californianos aliclaros en Seal Cove, pero ninguno fue recapturado. Encontramos nidos y/o huevos de mérgulos en 6 "refugios" de reproducción cercanos a la costa en Seal Cove y en el sudeste de la Isla San Clemente, que parecen ofrecer protección contra el zorro isleño (Urocyon littoralis clementae) y el gato domestico (Felis catus). Observarmos mérgulos de Scripps incubando 4 nidos, pero sólo encontramos huevos o cáscaras de huevos en otros 8 sitios. El éxito de eclosión total fue muy bajo (12\%, $n=17$ puestas) en 2012-2016, aposiblemnete debido a la competencia intra-específica por el número limitado de grietas para el establecimiento de nidos en Seal Cove y por la depredación (o el posible abandono y posterior consumo de huevos) por ratas negras (Rattus rattus) en SESCI. Utilizando los datos de los muestreos, estimamos 115 parejas de mérgulos (rango 79-208) en la Isla San Clemente, incluidos 110 parejas (rango 76-199) de mérgulos de Scripps y 5 parejas (rango 3-9) de mérgulos californianos aliclaros, aunque aún no se encontraron nidos de estos últimos.

*Corresponding author: darrellwhitworth@ciesresearch.org

$\dagger$ Deceased 
Análisis robustos de los datos obtenidos en Seal Cove indicaron que los muestreos realizados durante 9 noches al año por un período de 20 años, podrían detectar de forma confiable $(\geq 0.90)$ cambios mínimos en la población del $\pm 1.7 \%$ anual. Se requieren esfuerzos adicionales para: (1) confirmar el estado reproductivo de GUMU; (2) investigar métodos alternativos de control de ratas, con el fin de aumentar el éxito de eclosión en los refugios de mérgulos; y (3) mejorar los hábitats de reproducción para reducir la competencia intra-específica que se genera por los sitios de nidificación, e incrementar el número de nidos monitoreados.

Scripps's Murrelet (Synthliboramphus scrippsi; SCMU) and Guadalupe Murrelet (S. hypoleucus; GUMU) are small, secretive alcids (family Alcidae) that breed on islands over a restricted range between Point Conception, California, USA, and Punta Eugenia, Baja California, Mexico (Drost and Lewis 1995, Carter et al. 2005, Keitt 2005, Birt et al. 2012; Fig. 1). Murrelet research is challenging at most of these islands because nests are usually concealed in rocky crevices in remote, rugged coastal habitats where birds are strictly nocturnal in their activities at the colony (Murray et al. 1983, Drost and Lewis 1995, Whitworth et al. 2013). On most SCMU and GUMU breeding islands, native and introduced terrestrial predators (e.g., island foxes [Urocyon littoralis], feral cats [Felis catus], and black rats [Rattus rattus]) have further limited nesting to steep coastal habitats that serve as isolated breeding refuges for the small remnant murrelet populations (McChesney and Tershy 1998). As a result, the status, distribution, and population trends of SCMU and GUMU at most islands were poorly known over much of the 20th century (Drost and Lewis 1995). Over the last 20 years, a rangewide assessment of SCMU and GUMU has relied on nocturnal spotlight surveys (Whitworth and Carter 2014) and at-sea capture (Whitworth et al. 1997) of murrelets attending near-shore at-sea congregations, a behavior strongly associated with nesting on the adjacent shoreline (Hamilton et al. 2011, Whitworth and Carter 2018a). To date, SCMU congregations have been detected at 12 islands and GUMU congregations at 4 islands (Fig. 1; Birt et al. 2012, Whitworth et al. 2018).

San Clemente Island (SCI), California, is one of only 2 islands where SCMU and GUMU regularly congregate together. The small murrelet populations at SCI are vulnerable to many anthropogenic threats (e.g., nonnative predators, oil spills, artificial light pollution; McChesney and Tershy 1998, Carter et al. 2000, Burkett et al. 2003, Carter 2003), which led to listing of both species as threatened, endangered, or vulnerable by various government agencies and conservation organizations (Burkett et al. 2003, SEMARNAT 2010, IUCN 2017), although federal listing under the U.S. Endangered Species Act was considered "not warranted" by the U.S. Fish and Wildlife Service in 2016 (USFWS 2016). In 2008, recognizing the importance of the murrelet populations at SCI, the U.S. Navy (USN) established a cooperative agreement with the California Institute of Environmental Studies (CIES) to summarize the history and status of murrelets at SCI. Made aware that effective survey techniques had been developed to monitor the small but significant populations of SCMU and GUMU at SCI, the USN requested that CIES prepare a long-term monitoring plan. In 2012-2016, CIES conducted baseline murrelet studies to (1) better determine breeding distribution, (2) improve the population estimate, (3) establish the best methods for long-term population monitoring, (4) locate an adequate sample of nests to determine timing of breeding and hatching success, (5) establish a baseline for measuring future population trends, and (6) confirm breeding by GUMU. In this paper, we report the status and distribution of SCMU and GUMU at SCI and discuss options for population monitoring.

\section{Methods \\ Study Area}

SCI $\left(32^{\circ} 55^{\prime} \mathrm{N}, 118^{\circ} 30^{\prime} \mathrm{W}\right)$ is a large, semiarid island located about $100 \mathrm{~km}$ WNW of San Diego, California (Fig. 1), in a geologic province known as the Southern California Offshore Borderland, a series of northwesttrending basins and ridges between the southern California coast and the continental shelf (Shepard and Emery 1941). SCI is the fourth largest $\left(147 \mathrm{~km}^{2}\right.$, max. elevation $\left.599 \mathrm{~m}\right)$ and southernmost of the 8 California Channel Islands found in this region. The coastline of SCI is generally rocky, except for short stretches of sandy beaches in coves on the 


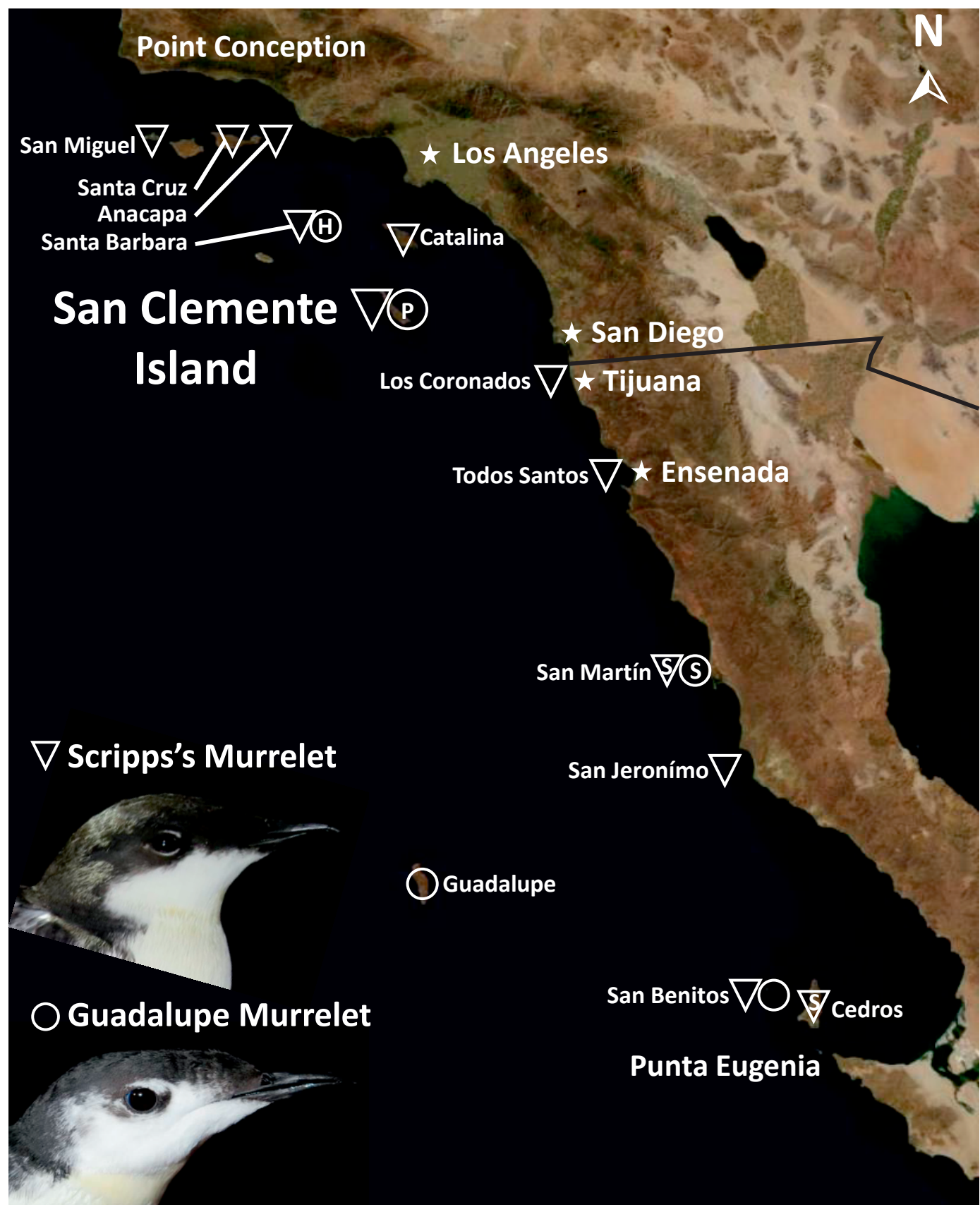

Fig. 1. Breeding ranges of Scripps's Murrelet and Guadalupe Murrelet on the Pacific Coast of southern California, USA, and Baja California, Mexico. Letters in symbols indicate the following: $\mathrm{H}=$ historical breeding (1977-1978), $\mathrm{P}=$ presumed breeding based on consistent murrelet attendance in at-sea congregations during the breeding season, $\mathrm{S}=$ suspected breeding based on isolated instance of murrelet(s) attending at-sea congregations during the breeding season.

north and south coasts. The southeast coast is characterized by high $(250-400 \mathrm{~m})$, moderately steep slopes with many sheer rock outcrops, while the west coast is characterized by low, rocky bluffs topped by marine terraces, although sheer 100-m coastal cliffs are present in Seal Cove on the west side of the island. Several small offshore rocks are scattered in 


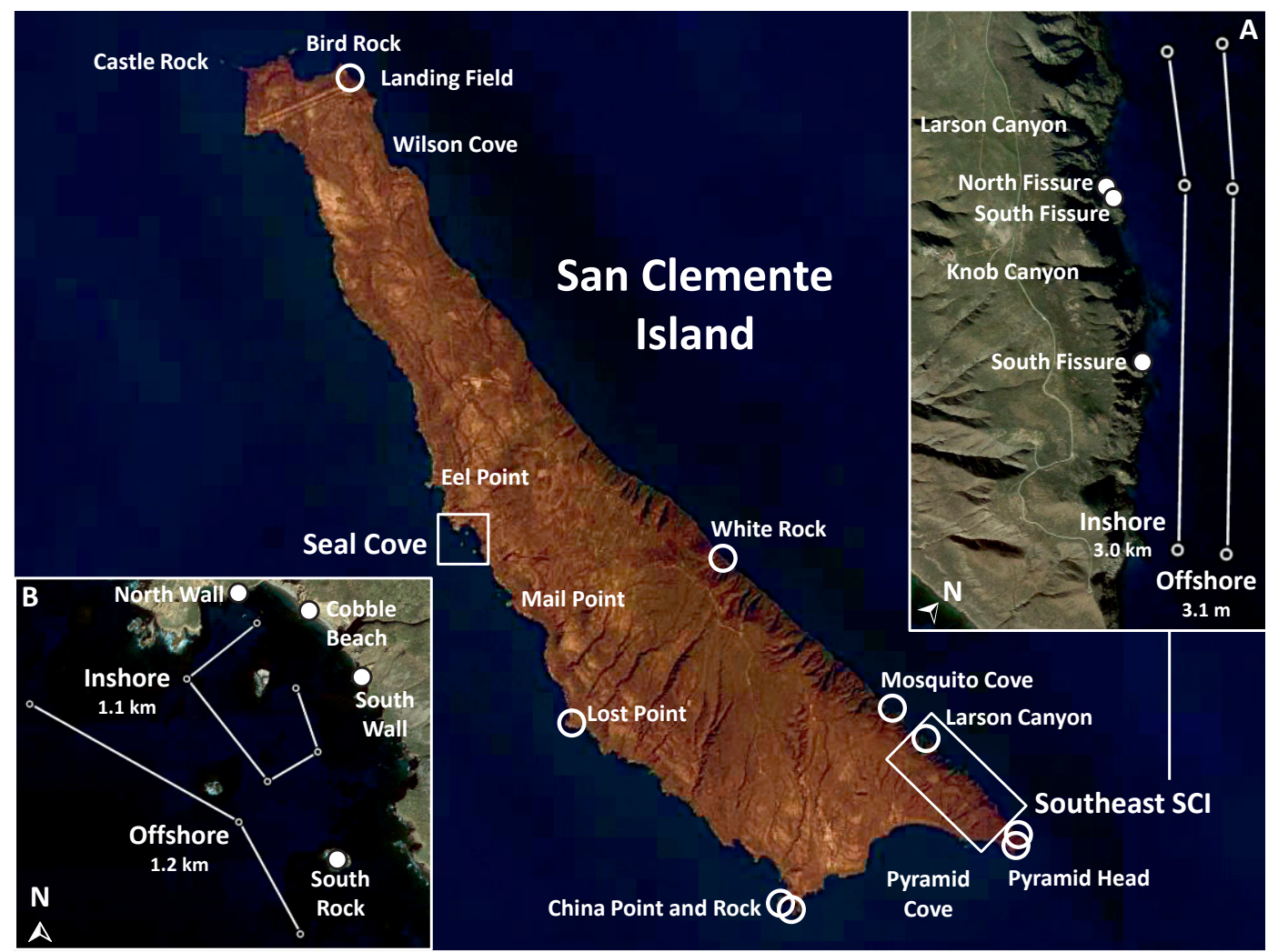

Fig. 2. San Clemente Island (SCI), California, with prominent landmarks and other locations mentioned in the text. Insets: (A) spotlight survey transects and murrelet breeding areas at southeast SCI and (B) spotlight survey transects and murrelet breeding areas at Seal Cove. Open circles indicate other areas where nest searches were conducted.

nearshore waters around SCI, mainly off the far north coast, Seal Cove, and China Point (Fig. 2). Coastal cliffs and offshore rocks support most breeding seabirds at SCI as these habitats offer protection from endemic island foxes (U. l. clementae), feral cats, and introduced black rats. The USN is the primary steward at SCI, which is an active military training location. Offshore rocks surrounding SCI are owned by the Bureau of Land Management and managed by the USN as part of the California Coastal National Monument.

\section{Spotlight Surveys}

All spotlight surveys followed the detailed methods described in Whitworth and Carter (2014). Standard surveys were conducted on inshore and offshore transects near the murrelet breeding areas at Seal Cove in 2013-2016 and the southeast shore of SCI (SESCI) in 2014-2016 (Fig. 2). The inshore transect $(1.1 \mathrm{~km})$ at Seal Cove covered the dense congregation within the cove, while the offshore transect $(1.2 \mathrm{~km})$ covered waters at the mouth of the cove. The inshore $(3.0 \mathrm{~km})$ and offshore $(3.1 \mathrm{~km})$ transects at SESCI ran parallel to the coast about $200 \mathrm{~m}$ and $500 \mathrm{~m}$ from shore, respectively.

Supplemental surveys outside the standard transects described above were conducted when time and conditions permitted, including (1) replicate surveys on a transect $(4.3 \mathrm{~km})$ between Eel Point and Mail Point in 2012-2013, (2) a single survey between Seal Cove and Pyramid Head $(\sim 24 \mathrm{~km})$ on 19-20 April 2013, and (3) a single survey between Larson Canyon and Wilson Cove $(\sim 25 \mathrm{~km})$ on 10-11 April 2014 (Fig. 2). Supplemental surveys followed transects that were part of the round-island survey conducted in 2008 (Appendix 1).

Standard spotlight surveys were conducted as early as 3 March and as late as 18 May (Table 1). We usually conducted 1-2 standard 
TABLE 1. Murrelet spotlight counts on the standard inshore and offshore transects at Seal Cove and the southeast shore (SESCI) of San Clemente Island, California, in 2013-2016.

\begin{tabular}{|c|c|c|c|c|c|c|}
\hline \multirow[b]{2}{*}{ Year } & \multicolumn{3}{|c|}{ Seal Cove } & \multicolumn{3}{|c|}{ SESCI } \\
\hline & Date & Inshore & Offshore & Date & Inshore & Offshore \\
\hline \multirow[t]{6}{*}{2013} & $19 \mathrm{Apr}$ & & 5 & & & \\
\hline & $20 \mathrm{Apr}$ & 45,35 & 11 & & & \\
\hline & $21 \mathrm{Apr}$ & 25,33 & 4 & & & \\
\hline & $22 \mathrm{Apr}$ & 12,25 & & & & \\
\hline & 17 Maya & $3,4,0$ & & & & \\
\hline & 18 Maya $^{\mathrm{a}}$ & 1,1 & & & & \\
\hline \multirow[t]{6}{*}{2014} & $28 \mathrm{Mar}$ & 20,17 & & $10 \mathrm{Apr}$ & 12,9 & 11,20 \\
\hline & $29 \mathrm{Mar}$ & 26 & & $14 \mathrm{Apr}$ & 10,2 & 16,25 \\
\hline & $12 \mathrm{Apr}$ & 26,30 & 6 & $29 \mathrm{Apr}$ & 2 & 7 \\
\hline & $13 \mathrm{Apr}$ & 36,28 & 2,2 & 2 May & 1,6 & 7,15 \\
\hline & $30 \mathrm{Apr}$ & 21,21 & 9,4 & & & \\
\hline & 1 May & 20,19 & 5,0 & & & \\
\hline \multirow[t]{4}{*}{2015} & $3 \mathrm{Mar}$ & 54,79 & 0,8 & $5 \mathrm{Mar}$ & 10 & 4 \\
\hline & 4 Mar & 16,36 & 11,1 & 6 Mar & 2,4 & 6,9 \\
\hline & 29 Mar & 23,30 & 0 & & & \\
\hline & 11 Maya & 3,4 & 1 & & & \\
\hline \multirow[t]{4}{*}{2016} & 3 Mar & $\begin{array}{c}33,41,9^{\mathrm{a}} \\
5^{\mathrm{a}}, 12^{\mathrm{a}}\end{array}$ & 4,6 & 5 Mar & 7,21 & 9,13 \\
\hline & 4 Mar & $4,5,0^{\mathrm{a}}, 7^{\mathrm{a}}$ & & $13 \mathrm{Mar}$ & $23,4^{\mathrm{a}}$ & $12,8^{\mathrm{a}}$ \\
\hline & 14 Mar & $27,26,3^{\mathrm{a}}$ & & $18 \mathrm{Mar}$ & 19,20 & 11,15 \\
\hline & $19 \mathrm{Mar}$ & 49,46 & 12,5 & & & \\
\hline
\end{tabular}

aSpotlight counts conducted after midnight or after 10 May and excluded from annual and baseline survey means.

spotlight surveys between 20:00 (PST) and midnight each night, although as many as 5 surveys were conducted as late as 04:10 within a night. To avoid biasing means, 11 standard inshore counts at Seal Cove and a pair of standard inshore/offshore counts at SESCI were excluded from annual and baseline means because these surveys were conducted after midnight or after 10 May when counts were invariably low (range 0-12 murrelets; Table 1). All spotlight surveys were conducted within a narrow range of ocean and weather conditions that ensured similar detectability of murrelets among surveys (see Whitworth and Carter 2014).

Population ESTIMATION.-To estimate population size, we used a spotlight survey correction factor (1.60 nests/murrelet; 95\% CI 1.102.89) that quantified the relationship between the mean number of murrelets counted during spotlight surveys and the number of nests found on the adjacent coastline at Santa Barbara Island, California (D. Whitworth unpublished data). To obtain a complete roundisland spotlight count, we summed spotlight counts from around SCI, including (1) the baseline mean inshore count at Seal Cove in 2013-2016, (2) the baseline mean inshore count at SESCI in 2014-2016, (3) the mean count on the Eel Point-to-Mail Point supple- mental transect in 2012-2014, and (4) single spotlight counts conducted around the remainder of the island in 2008 (Appendix 1), 2013, and 2014. The presence of both SCMU and GUMU required spotlight counts at Seal Cove to be adjusted by the overall proportion of each species in the at-sea capture sample. Murrelets observed outside Seal Cove were all assumed to be SCMU because GUMU have not been seen or heard outside of Seal Cove.

Power analysis.-We used Program Monitor v.11.0.2 beta (Gibbs and Ene 2010) to examine the statistical power $(1-\beta)$ of various spotlight survey monitoring plans to detect murrelet population trends at Seal Cove. Power (i.e., the probability of detecting a trend in sample measurements when, in fact, a trend has occurred) was plotted against a range of per annum population changes to determine the efficacy of the various monitoring plans. Specific input parameters for Program Monitor were as follows: (1) simple regression design; (2) log-normal measures; (3) total variance estimated from baseline data (see below); (4) deterministic regression trends with $-10 \%$ minimum and $+10 \%$ maximum measured at $1 \%$ intervals; (5) constant CV over time; (6) significance at $P=0.05$; (7) number of iterations $=10,000$; (8) desired power level $=0.90$; (9) 2-tailed tests; and (10) integer rounding. 
The overall mean and standard deviation from baseline inshore surveys at Seal Cove in 2013-2016 were used as the starting value and total variation inputs for Program Monitor simulations. Monitoring periods were 12 years (2013 to 2024) or 20 years (2013 to 2032). Three levels of annual survey effort were considered: (1) high-effort $=18$ surveys over 9 nights; (2) medium-effort $=12$ surveys over 6 nights; and (3) low-effort $=6$ surveys over 3 nights. We considered 3 monitoring intervals, including baseline surveys in 2013-2016 with 1-3 years off, followed by (1) annual monitoring beginning in 2018; (2) 2 years on and 2 years off (hereafter " $2 / 2$ ") beginning in 2019; and (3) 1 year on and 3 years off (hereafter " $1 / 3$ ") beginning in 2020. All 18 combinations of the 2 monitoring periods, 3 annual survey efforts, and 3 survey intervals were examined.

\section{At-Sea Captures}

We used the night-lighting technique (Whitworth et al. 1997) to capture murrelets attending congregations at Seal Cove and SESCI (Fig. 2). All captured murrelets were processed in an inflatable boat and released within 2-3 min near the capture location. Handling procedures included (1) application of a U.S. Geological Survey \#2 stainless steel leg band; (2) examination for presence of bilateral brood patches to assess breeding status (Sealy 1974); and (3) determination of species from facial plumage (Jehl and Bond 1975). To avoid affecting spotlight counts, captures were conducted after all spotlight surveys had been completed each night.

\section{Nest Searches and Monitoring}

Nest searches were conducted in potential breeding habitats to locate a sample of nests for monitoring reproductive success and timing of breeding (e.g., Whitworth et al. 2005, 2013). Small handheld flashlights were used to search suitable crevices for evidence of breeding (i.e., incubating or brooding adult, unattended eggs, and broken or hatched eggs). All crevices with evidence of breeding were tagged with numbered aluminum discs. Nest searches were conducted during the breeding season (March-May) in (1) all accessible habitats at Seal Cove, (2) 3 fissures on the shoreline of SESCI, and (3) other shoreline areas located mainly on the southern half of SCI (Fig. 2).

\section{Results}

Spotlight Surveys

SEAL Cove (2013-2016).- - Standard offshore counts ranged from 0 to 12 murrelets $(n=20)$, and inshore counts ranged from 0 to 79 murrelets $(n=44$; Table 1$)$. We noted significant differences (paired $t_{18}=7.47, P<0.0001$ ) but no correlations $\left(r_{17}^{2}=0.06, P=0.32\right)$ between paired inshore/offshore counts. The mean inshore count $(22 \pm 17[\bar{x} \pm \mathrm{SD}])$ was much higher than the mean offshore count $(5 \pm 4)$. In fact, offshore counts were invariably low ( $\leq 12$ murrelets) throughout the breeding season in all years. Thus, at Seal Cove we considered inshore counts superior for monitoring purposes and excluded offshore counts from trend and power analyses.

After excluding late-night and late-season surveys (see methods), we found no differences (ANOVA: $F_{3,27}=1.48, P=0.24$ ) among annual mean inshore counts (2013: $29 \pm 11$, $n=6 ; 2014: 24 \pm 6, n=11 ; 2015: 40 \pm 23, n=$ 6; 2016: $29 \pm 17, n=8$ ). No trends were evident $\left(r^{2}=0.09, P=0.70\right)$ for the annual mean counts over the 2013-2016 survey period. The baseline mean inshore count at Seal Cove was $29 \pm 15$ murrelets $(n=31)$ in 2013-2016.

Southeast SCI (2014-2016).--Standard inshore counts ranged from 1 to 23 murrelets $(n=16)$ and offshore counts ranged from 4 to 25 murrelets $(n=16$; Table 1). No significant differences (paired $t_{15}=1.04, P=0.31$ ) or correlations $\left(r^{2}=0.02, P=0.60\right)$ were noted between the paired inshore/offshore counts (paired counts).

After excluding one survey conducted after midnight, SESCI paired counts ranged from 8 to 35 murrelets and the baseline mean was $22 \pm 10$ murrelets $(n=15)$ in 2014-2016. Annual mean paired counts were $20 \pm 9$ murrelets $(n=7)$ in 2014, $12 \pm 3(n=3)$ in 2015, and $30 \pm 8(n=5)$ in 2016. We doubted that the small sample of 2015 surveys was representative, so we did not perform ANOVA to compare means among years or regression to examine trends over the 3-year survey period. However, we did not detect differences $\left(t_{10}=\right.$ 1.95, $P=0.08$ ) between the 2014 and 2016 annual means.

SuPPLEMENTAL SURVEYS.-Spotlight counts on the supplemental transect between Eel Point and Mail Point in 2012-2013 ranged from 1 to 21 murrelets $(\bar{x}=8 \pm 6, n=9)$. We 

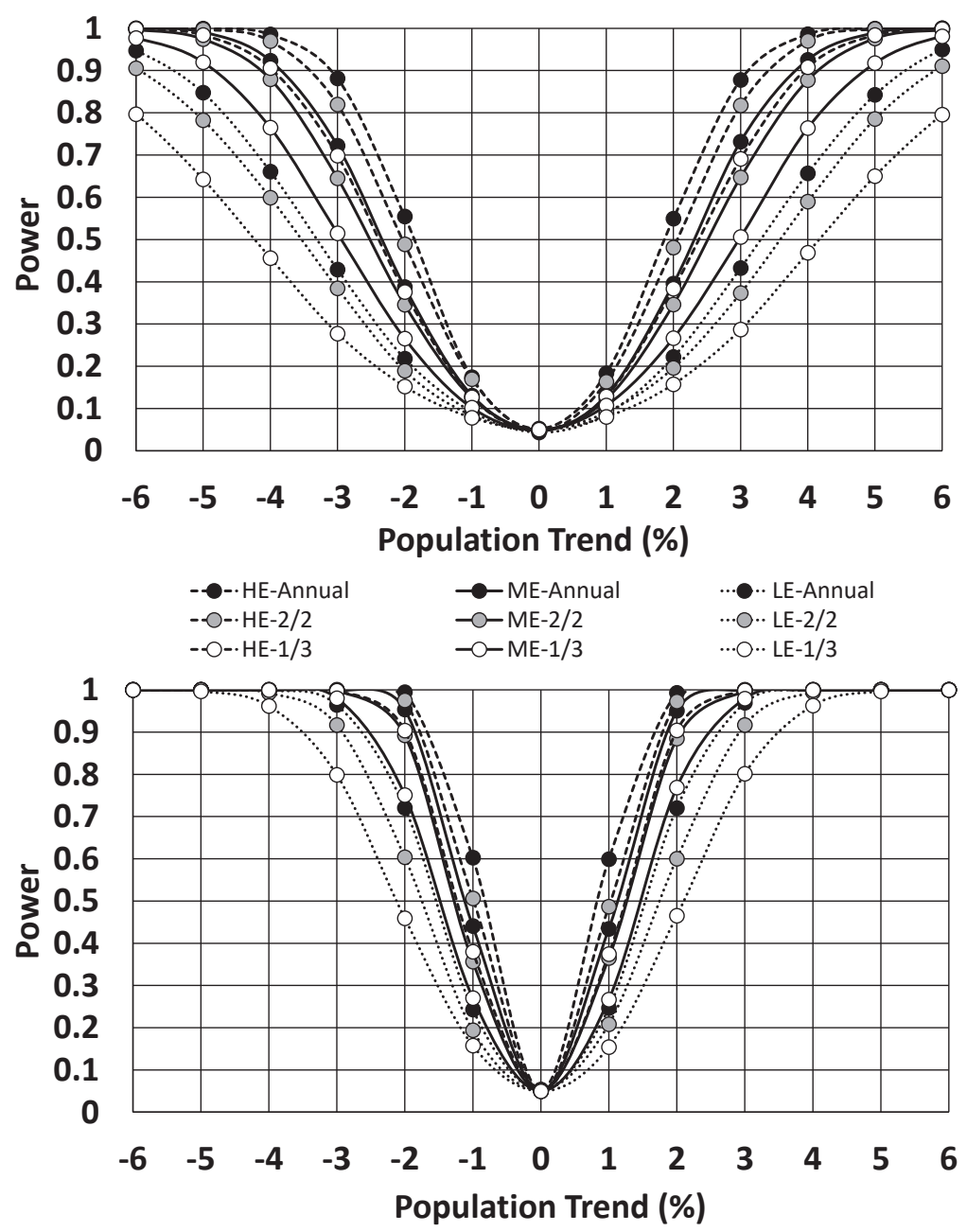

Fig. 3. Power to estimate murrelet population trends for 12-year (upper) and 20-year (lower) spotlight survey monitoring periods at Seal Cove, San Clemente Island, California. Charts show power for high-effort (HE), medium-effort (ME), and low-effort (LE) monitoring plans conducted annually; 2 years on, 2 years off ( $2 / 2)$; and 1 year on, 3 years off $(1 / 3$; see methods).

counted 5 murrelets during the single supplemental survey between Mail Point and China Point in 2013 and 17 murrelets during the single survey between Larson Canyon and Wilson Cove in 2014. Fifteen of the 17 murrelets counted in 2014 were within $6 \mathrm{~km}$ of Wilson Cove.

POPULATION ESTIMATE.-The mean spotlight counts from the Seal Cove inshore transect (29 murrelets), SESCI inshore transect (10 murrelets), and Eel Point-to-Mail Point transect (8 murrelets) combined with counts from single surveys conducted around the remainder of the island (25 murrelets) yielded a round-island count of 72 murrelets. Applying the spotlight survey correction factor and a 95\% confidence interval to the round-island count yielded 115 breeding pairs (range 79-208) at SCI in 2012-2016. Based on the overall proportions of SCMU (89\%) and GUMU (11\%) captured in the congregation at Seal Cove, we estimated 110 pairs (range 76-199) of SCMU breeding at SCI and just 5 pairs (range 3-9) of GUMU limited to the Seal Cove area, although a GUMU nest has not yet been found.

Power ANALYsis.-As expected, power analyses revealed that more intensive spotlight 
TABLE 2. Minimum detectable population change per annum (power $\geq 0.90$ ) for various levels of spotlight survey monitoring at Seal Cove, San Clemente Island, California. Numbers in parentheses indicate the total population decline over the 20 -year or 12 -year monitoring period.

\begin{tabular}{llcc}
\hline & & \multicolumn{2}{c}{ Monitoring duration } \\
\cline { 2 - 3 } Survey interval & Annual-effort & 20-year $(2013-2032)$ & 12-year $(2013-2024)$ \\
\hline Annual & High & $\pm 1.7 \%(-28 \%)$ & $\pm 3.1 \%(-29 \%)$ \\
& Medium & $\pm 1.8 \%(-29 \%)$ & $\pm 3.8 \%(-35 \%)$ \\
2 years on/2 off & Low & $\pm 2.7 \%(-41 \%)$ & $\pm 5.4 \%(-46 \%)$ \\
& High & $\pm 1.8 \%(-29 \%)$ & $\pm 3.4 \%(-32 \%)$ \\
1 year on/3 off & Medium & $\pm 2.0 \%(-32 \%)$ & $\pm 4.2 \%(-38 \%)$ \\
& Low & $\pm 2.9 \%(-43 \%)$ & $\pm 6.0 \%(-49 \%)$ \\
& High & $\pm 2.0 \%(-32 \%)$ & $\pm 4.8 \%(-36 \%)$ \\
& Medium & $\pm 2.5 \%(-38 \%)$ & $\pm 6.9 \%(-54 \%)$ \\
\hline
\end{tabular}

TABLE 3. Annual capture totals for Scripps's Murrelets and Guadalupe Murrelets at Seal Cove and southeast San Clemente Island (SESCI), California in 2012-2016.

\begin{tabular}{|c|c|c|c|c|c|}
\hline \multirow[b]{2}{*}{ Area } & \multirow[b]{2}{*}{ Year (nights) } & \multicolumn{2}{|c|}{ Scripps's Murrelet } & \multicolumn{2}{|c|}{ Guadalupe Murrelet } \\
\hline & & Banded (recaptured $\left.{ }^{a}\right)$ & Breeding & Banded & Breeding \\
\hline \multirow[t]{6}{*}{ Seal Cove } & $2012(5)$ & 38 & $20(53 \%)$ & 4 & $1(25 \%)$ \\
\hline & $2013(6)$ & $47(1)$ & $20(42 \%)$ & 6 & $1(17 \%)$ \\
\hline & $2014(6)$ & $35(6)$ & $19(46 \%)$ & 6 & $1(17 \%)$ \\
\hline & 2015 (3) & $25(9)$ & $1(4 \%)$ & 2 & - \\
\hline & $2016(3)$ & $13(2)$ & $1(7 \%)$ & 3 & - \\
\hline & TOTAL (23) & $158(18)$ & $61(39 \%)$ & 21 & $3(14 \%)$ \\
\hline \multirow[t]{4}{*}{ SESCI } & $2014(3)$ & 9 & $2(22 \%)$ & - & - \\
\hline & $2015(1)$ & 5 & $1(20 \%)$ & - & - \\
\hline & $2016(2)$ & $29(1)$ & $9(30 \%)$ & - & - \\
\hline & TOTAL $(6)$ & $43(1)$ & $12(28 \%)$ & - & - \\
\hline
\end{tabular}

aExcludes murrelets banded and recaptured in the same year.

surveys (i.e., higher annual effort and shorter monitoring intervals) had greater power to detect trends over the 12-year and 20-year monitoring periods (Fig. 3). The most intensive (i.e., high-effort annual surveys) monitoring program could reliably $(1-\beta \geq 0.90)$ detect minimum population changes of $\pm 1.7 \%$ per annum over 20 years, while a similar 12 -year program could only detect changes as low as $\pm 3.1 \%$ per annum (Table 2 ). A less intensive monitoring effort (i.e., medium-effort $2 / 2$ surveys) over 20 years yielded reliable power to detect $\pm 2.0 \%$ per annum changes, while similar effort over 12 years could only detect $\pm 4.2 \%$ per annum changes.

Low-effort surveys performed relatively poorly regardless of survey interval or period. At $1-\beta \geq 0.90$, none of the 20 -year low-effort monitoring plans detected population changes less than $\pm 2.7 \%$ per annum and none of the 12-year low-effort plans detected changes less than $\pm 5.4 \%$ per annum. The power to detect trends remained relatively consistent within effort classes among the different survey intervals (Table 2); annual surveys were marginally better at detecting trends compared to the $2 / 2$ interval, but the $1 / 3$ interval was much less effective at detecting trends across all effort classes.

\section{At-Sea Captures}

We banded 201 SCMU at SCI: 158 at Seal Cove in 2012-2016 and 43 at SESCI in 2014-2016 (Table 3). Nineteen SCMU were recaptured (not including recaptures in the year banded), with all but one recapture occurring at Seal Cove. The proportion of recaptured SCMU (percent of the annual capture sample that was banded in a previous year) at Seal Cove increased each year as more murrelets were banded; recaptures accounted for $2 \%$ of all captures in 2013, $15 \%$ in 2014 , and $26 \%$ in 2015 , but decreased to $13 \%$ in 2016 . Overall, $12 \%$ of the SCMU banded at Seal Cove in 2012-2015 were recaptured in 2013-2016, and 7\% of 
TABLE 4. Occupancy and clutch fates of monitored murrelet nests at Seal Cove and southeast San Clemente Island (SESCI) nesting areas in 2012-2016. Clutch fates: hatched $\bullet$; abandoned $\Theta$; depredated or scavenged $\otimes$; unknown $\diamond$. Shaded cells indicate years before nest monitoring was conducted or after sites had been destroyed.

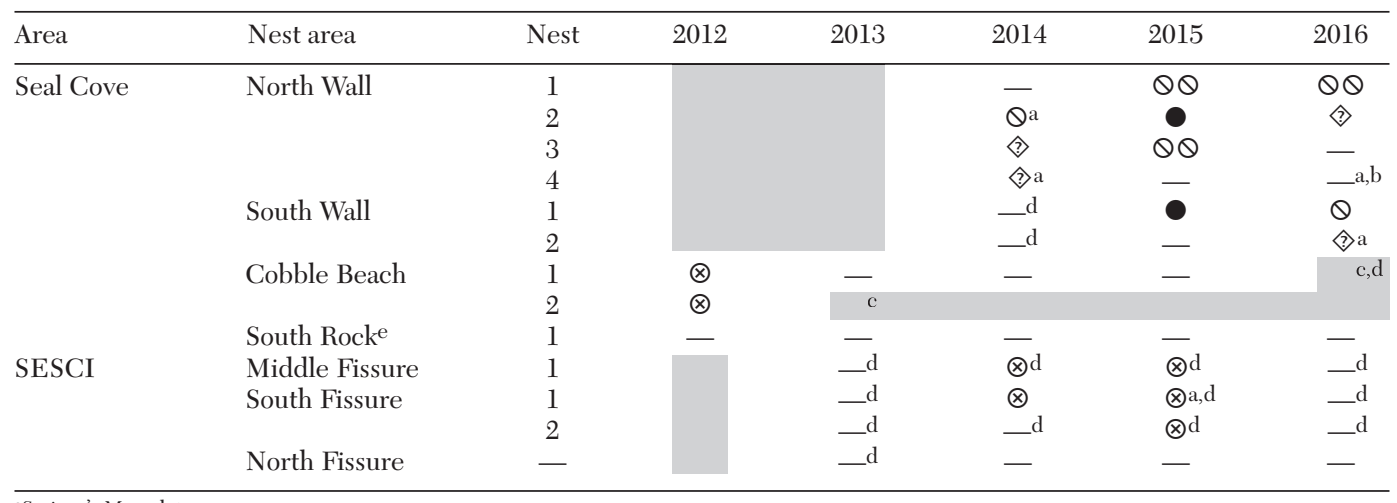

aScripps's Murrelet

bDead adult.

cDestroyed by erosion in 2013 or 2016.

dEggshells were found in the area but could not be assigned to a specific crevice.

eBreeding documented in 1994.

the SCMU banded at SESCI in 2014-2015 were recaptured in 2015-2016. The proportion of SCMU with brood patches (indicating that eggs had been laid by the individual or its mate) captured at Seal Cove was higher in 2012-2014 (42\%-53\%) when captures occurred in April and May, compared to 2015-2016 (4\%-7\%) when most captures occurred in March. The proportion breeding was relatively consistent at SESCI in 2014$2016(22 \%-30 \%)$.

We banded 21 GUMU in Seal Cove, but none were recaptured (Table 3 ). The overall proportion of GUMU in the sample captured at Seal Cove (including recaptured SCMU) was $11 \%(n=197)$ but varied from $6 \%$ in 2015 to $17 \%$ in 2016. One breeding GUMU was captured each year in 2012-2014 but none in 2015-2016.

\section{Nest Searches and Monitoring}

Evidence of breeding was found in 6 discrete areas since 2012 (Table 4). Nests were first found on the Cobble Beach at Seal Cove in 2012, the Middle Fissure and South Fissure at SESCI in 2013, and the North Wall and South Wall at Seal Cove and the North Fissure at SESCI in 2014 (Fig. 2, Table 4). Including South Rock at Seal Cove (where a nest was found in 1994), we monitored a total of 12 nest sites in 7 breeding areas, although nests found at Cobble Beach in 2012 were destroyed by erosion in 2013 and 2016. Incubating SCMU were seen in 4 nest sites, but only eggs or eggshell fragments were found in the other 8 sites. We found no evidence of murrelet breeding during nest searches in the following areas (Fig. 2): (1) North Rock at Seal Cove (2012-2014); (2) offshore rocks at China Point (2012-2013); (3) rocky scree on the slopes and bluffs above Seal Cove (2013); (4) caves at Seal Cove, Lost Point, Pyramid Head, and Mosquito Cove (2013); (5) the shoreline at Mosquito Cove, Larson Canyon, Pyramid Head, and below the Landing Field (2013); and (6) White Rock and the adjacent shoreline (2013). Evidence of mammals was found in all these areas except North Rock and White Rock.

Overall, 21 clutches were laid in monitored sites from 2012 to 2016 , with 2 clutches in 2 sites in 2012, no clutches in 2013, 5 clutches in 5 sites in 2014, 9 clutches in 7 sites in 2015, and 5 clutches in 4 sites in 2016 (Table 4). However, undetected nests undoubtedly occurred in some areas, mainly at SESCI, as indicated by many exposed eggshells that had fallen or been removed from nests and could not be assigned to specific sites. Hatching success was very low, with only $2(12 \%)$ hatched of 17 clutches with known fates; 4 clutches had unknown fates. The only hatched clutches in 2012-2016 occurred in the North and South Wall areas at Seal Cove in 2015.

All 5 clutches in SESCI breeding areas were depredated, presumably by rats as evidenced by feces, food caches, and chewed 


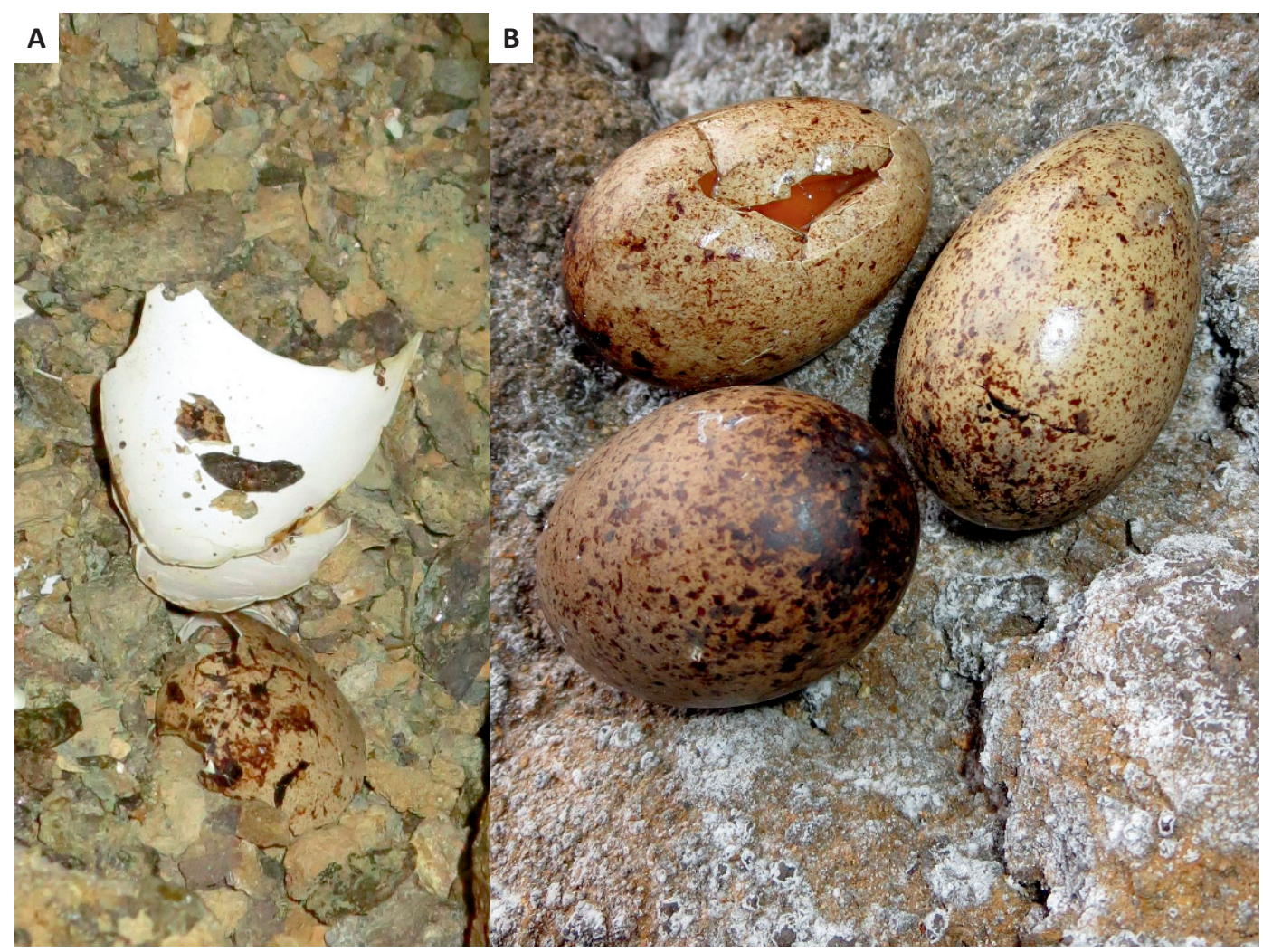

Fig. 4. Murrelet eggs from failed clutches at San Clemente Island, California, in 2015: A, rat-depredated eggshell (rat feces are visible) from Middle Fissure at southeast San Clemente; B, 3-egg supernormal clutch with damaged egg from North Wall at Seal Cove.

eggshells (Fig. 4a), although clutch abandonment and subsequent egg scavenging by rats or foxes was also a possibility. In contrast, only 2 depredated clutches (both at Cobble Beach in 2012), but 8 abandoned clutches, were recorded at Seal Cove. Typical murrelet clutches contain 2 eggs (Murray et al. 1983), but we documented 3 supernormal clutches (i.e., $\geq 3$ eggs laid concurrently by 2 pairs; Fig. 4b) that accounted for 6 of the 8 abandoned clutches at Seal Cove, suggestive of intraspecific competition for limited nest sites. Cracked, dented, or punctured eggs in supernormal clutches (Fig. 4b) were consistent with damage that might occur during scuffles between adults and supported the assumption of intraspecific nest site competition. Intraspecific disturbance also may have played a role in the abandoned clutch at South Wall in 2016, as a dented egg was found in one of the 2 monitored nests that shared a common entrance on this narrow ledge.

\section{Discussion}

Population Size and Trends

Comparisons of spotlight counts from all the murrelet breeding islands in southern California and Baja California indicated that SCI currently hosts one of the smallest SCMU colonies ( $<200$ pairs) and probably the smallest GUMU colony (perhaps $<10$ pairs) in the world (e.g., Whitworth et al. 2014, Whitworth and Carter 2018a, 2018b; CIES unpublished data). Despite its small overall size, the murrelet population at SCI is clearly much larger than previously thought over the last century. Murrelets (presumably SCMU) observed or collected at-sea near SCI led to the first suggestions of breeding at the island in the late 1800s and early 1900s (Cooper 1870, Linton 1909, Willett 1912, Howell 1917). Howell (1917:22) speculated that breeding at SCI was "highly improbable, however, except that a few pairs may possibly be found on a large 
rock near the western end," and Grinnell and Miller (1944) did not list SCI as a breeding location. Family groups with small chicks observed at-sea near SCI in 1968 and 1975 provided more compelling evidence of breeding (Hunt et al. 1979, Jorgensen and Ferguson 1984). Direct evidence of nesting was finally reported in 1977 when a hatched eggshell was found near Seal Cove (Hunt et al. 1980). However, Hunt et al. (1980:452) considered the SCI population "almost insignificant." The first recognition of a significant murrelet population at SCI was in 1994-1996 when extensive at-sea vocalization surveys detected a small population (10-50 pairs; see Burkett et al. 2003) breeding mainly at Seal Cove, but with scattered individuals and pairs heard off the northeast and southeast shores (Appendix 1). With scant historical information and only limited recent data, the murrelet population was still perceived as negligible as recently as 2005 when Sullivan et al. (2005:214) reported murrelets as a "very rare migrant and visitor; current breeding status unknown."

With only a few speculative population assessments since the early 1900s, there were no reliable data to assess historic or recent population trends at SCI. However, we doubt there has been a significant increase in population size over the last century given the abundance of terrestrial predators that have long restricted murrelets to isolated and mostly inaccessible breeding refuges. Previous assessments that considered murrelet breeding as "improbable" and the population as "insignificant" probably reflected more the difficulties of studying these secretive species than the actual size of the population. Since 2012, the spotlight survey technique has provided standardized quantitative data that better represent the size of the murrelet population at SCI, which is now the best studied of the 3 small colonies in California (i.e., San Miguel, Santa Catalina, and San Clemente Islands).

The baseline data established in 2013-2016 have provided a reliable reference for monitoring future trends. Ideally, a long-term murrelet monitoring program would use multiple independent techniques to confirm population trends, as demonstrated at Anacapa Island, California, where annual nest monitoring and nonannual spotlight surveys detected similar rates of murrelet population increase $(12 \%-15 \%$ per annum) after the eradication of rats in
2002 (Whitworth and Carter 2018a). Nest monitoring over many years should allow detection of major population changes at SCI. A larger sample of nests is desirable, but would likely be obtainable only with enhancements to current breeding habitats such as localized rodent control to reduce rat predation at SESCI or artificial nest sites to alleviate the shortage of natural crevices at Seal Cove. More frequent visits early in the breeding season might increase the number of monitored nests by detecting some clutches before they are depredated and the eggshells moved out of nest crevices. Even with larger samples, there is still some question whether monitored nests are representative of the overall population because most murrelets probably breed in inaccessible habitats where hatching success may be higher. Spotlight surveys have the great advantage of gathering data on murrelets nesting in all habitats; thus, a combination of spotlight surveys and nest monitoring provides the most reliable means of assessing and confirming overall population trends.

The choice of a spotlight survey monitoring program is essentially a compromise between reasonable level of survey effort (i.e., cost) and adequate power to detect population change. The main factors affecting the power of a monitoring program include variability in the monitoring data, annual survey effort, intervals (if any) between monitoring years, and the overall duration of the monitoring program. Given the relatively low power of 12-year monitoring, low-effort surveys, and the $1 / 3$ survey interval (Fig. 3, Table 2), we did not consider these options adequate for careful tracking of murrelet population trends (e.g., Cohen 1988). Considering the remaining options, the power of a 20 -year monitoring program to detect a $2 \%$ per annum population decrease at Seal Cove was 0.99 for higheffort annual surveys, 0.98 for high-effort $2 / 2$ surveys, 0.95 for medium-effort annual surveys, and 0.89 for medium-effort $2 / 2$ surveys. Any of these 4 options might be acceptable given that 0.80 is considered the conventional value for adequate power to detect trends (Cohen 1988).

\section{Status of Guadalupe Murrelet}

Confirmation of GUMU breeding at SCI was the only project goal that we did not 
achieve. For many decades, SCMU was assumed to be the only species (or subspecies) breeding at SCI. The possibility of breeding by GUMU was not considered, mainly because only SCMU were known to regularly breed at the 7 colonies nearest to SCI (Fig. 1). In fact, sympatric breeding by GUMU was not suspected until small numbers were consistently captured from the congregation at Seal Cove in 1994, 1998, and 2008 (Appendix 1); subsequent captures (including adults with brood patches) in 2012-2016 (Table 3) further supported the presumption of GUMU breeding. The regular presence of GUMU demonstrated an affinity for the congregation at Seal Cove that was notably lacking at SESCI and the other 7 SCMU breeding islands from San Miguel Island, California, to Todos Santos, Baja California (Fig. 1). Only 4 GUMU $(<0.005 \%)$ were reported among the $1600+$ murrelets captured outside Seal Cove since 1994 (Whitworth et al. 1997; CIES unpublished data). In contrast, $30(15 \%)$ of the 206 murrelets captured at Seal Cove since 1994 were GUMU (Table 3, Appendix 1). Furthermore, GUMU at the other islands (single birds at Santa Cruz and Santa Barbara, and a pair at Anacapa) were all captured between mid-May and July, but most GUMU (90\%) at Seal Cove were captured in March and April. Despite this credible indirect evidence of GUMU breeding at Seal Cove, direct evidence is desirable because alternate interpretations of their presence are plausible. GUMU at SCI could simply have been visitors dispersing northward from the 2 recognized colonies at Guadalupe and the San Benito islands $400-600 \mathrm{~km}$ to the south (Fig. 1; Briggs et al. 1987, Karnovsky et al. 2005). Guadalupe Island hosts the bulk of the world population (Keitt 2005; CIES unpublished data), while San Benito is the only location where GUMU and SCMU are currently known to breed sympatrically (Wolf et al. 2005). A single GUMU was captured among SCMU and Craveri's Murrelets (S. craveri) at San Martín Island, Baja California (Fig. 1), but captures there were conducted on just one night, so it is unclear if GUMU regularly attend this island (Whitworth et al. 2018).

GUMU breeding on the California Channel Islands is not unprecedented; a single nest was reported at Santa Barbara Island in 1977-1978 (Winnett et al. 1979). If GUMU do currently breed at SCI, nesting most likely occurs at the south end of Seal Cove where they are most commonly captured. Unfortunately, most of the potential nest sites at Seal Cove are in 100-m-tall eroding cliffs, which would be difficult to search even with climbing equipment. We confirmed SCMU in 3 of the 9 nests in the Seal Cove area (Table 4), but eggs or eggshells were the only evidence of breeding observed in the other nests. Given the small number of murrelet nests found at Seal Cove and the low proportion of GUMU in the overall murrelet population, the chances of finding an incubating GUMU adult in a nest are remote. Species identification of eggs/eggshells was not possible because methods to distinguish between SCMU and GUMU eggs by color or measurements have not yet been developed and funding to conduct genetic analysis was not available. Genetic examination of eggs or radiotelemetry to determine movements of tagged adults that are consistent with breeding are perhaps the best options for confirming breeding by GUMU.

\section{Murrelet Breeding at San Clemente Island}

BREEDing Distribution.-As at other islands inhabited by terrestrial predators (e.g., San Miguel, Santa Catalina, and Guadalupe Islands; Keitt 2005, Whitworth et al. 2014, Whitworth and Carter 2018b), murrelet breeding in isolated refuges has been a key factor in their persistence on SCI. In the early 1900s, A.B. Howell (quoted in Bent 1919:149) remarked that "the presence of foxes on the larger islands of southern California precludes them from breeding on these, but ... they may breed on whatever islets offer them suitable conditions." Hunt et al. (1980:452) inferred that the murrelet population at SCI was "probably rigorously held in check by the abundant terrestrial predators there." Terrestrial predators are broadly distributed in a variety of habitats around SCI (Phillips et al. 2007, Bridges et al. 2015, Higgins et al. 2015), and we found abundant evidence of them in most of the accessible shoreline areas and caves we searched. We have not detected any evidence of foxes or cats preying on murrelets, but foxes have recently been detected by motion-sensitive cameras in the South Fissure breeding area at SESCI (CIES unpublished data). In contrast, evidence of rats (e.g., food caches and feces) and rat-depredated murrelet 
eggs and adults have been found annually at SESCI and the Cobble Beach at Seal Cove. Remnant murrelet populations have also persisted in some rat-infested habitats at San Miguel, Santa Catalina, and (prior to rat eradication in 2002) Anacapa Islands (Whitworth et al. 2013, 2014, Whitworth and Carter 2018b).

Offshore rocks often provide important breeding refuges for murrelets at islands where terrestrial predators inhabit the main island; for example, Prince Islet hosted the bulk of the SCMU population at San Miguel (Whitworth and Carter 2018b), and most GUMU at Guadalupe Island nested on 3 large predator-free offshore rocks (Keitt 2005; CIES unpublished data). While some offshore rocks at SCI appeared to contain potential breeding crevices, the eggs found on South Rock in 1994 are the only offshore rock breeding record to date, although small numbers of crevice-nesting Ashy Storm-Petrels (Oceanodroma homochroa) and Leach's Storm-Petrels (O. leucorhoa) breed there (CIES unpublished data). We still consider Castle Rock to be a possible breeding location because 3 murrelets were observed nearby during the round-island spotlight survey in 2008 (Appendix 1), but frequent security closures prevented nest searches and spotlight surveys there in 2012-2016. None of the other offshore rocks at SCI appeared suitable for breeding; White Rock and Seal Cove North Rock contained few suitable nest crevices, while rocks off China Point were either partially inundated at high tide or accessible to terrestrial predators at low tide.

Scattered murrelet individuals or pairs were consistently detected near Wilson Cove during vocalization surveys in 1994 (Appendix 1) and spotlight surveys in 2008 and 2014, even though the adjacent shoreline appeared to offer no suitable breeding habitat and was easily accessible to terrestrial predators. Murrelet presence near Wilson Cove may be explained by attraction to lights from buildings and anchored vessels (Whitworth et al. 1997, Carter et al. 2000). However, thorough nest searches and additional spotlight surveys are needed to better assess the possibility of nesting on the northeast coast of SCI.

Hatching suCCEss.-The current sample of monitored nests $(n=10)$ at SCI is small, but has been adequate for estimates of occupancy and hatching success since 2014. Hatching success is the only reliable measure of productivity for Synthliboramphus murrelets because precocial chicks depart the nest 2 nights after hatching and are raised at sea (Sealy 1976, Murray et al. 1983). Overall hatching success at SCI in 2012-2016 was very poor $(12 \%)$ compared to islands where introduced predators have been eradicated; hatching success was 30\% before (2001-2002) and $85 \%$ after (2003-2014) the eradication of rats at Anacapa (Whitworth et al. 2013), $26 \%-71 \%$ at Santa Barbara in 1993-2003 (Schwemm and Martin 2005), 35\%-52\% at the San Benitos in 2003-2004 (Wolf et al. 2005), and 47\%-68\% at South Coronado in 2005-2007 (CIES unpublished data). The absence of introduced terrestrial predators on these islands allowed for much larger samples of monitored nests. Hatching success was also high $(75 \%)$ for the small sample of nests in breeding refuges on Santa Catalina in 2012-2013 (Whitworth et al. 2014), even though foxes, cats, and rats were present over much of the island (McChesney and Tershy 1998).

We documented 2 distinct factors responsible for the poor hatching success at SCI: pervasive egg predation (or possibly scavenging) by rats at SESCI and intraspecific competition for limited nest crevices at Seal Cove. Protection and enhancement of the breeding refuges may be crucial to the continued survival of the small murrelet populations at SCI. Depredated eggs at Cobble Beach in 2012 provided the first evidence of rat impacts on murrelets at SCI, but more severe impacts have since been documented at SESCI in 2013-2016. Localized rodent control measures began at Cobble Beach in 2013 (IWS unpublished data) but have not yet yielded any obvious benefit to murrelets. Expansion of rodent control efforts to SESCI murrelet breeding areas should be considered immediately because the current level of predation by rats at SESCI may be unsustainable; extirpation in monitored areas is a distinct possibility as no clutches were detected in monitored nests at SESCI in 2017 (CIES unpublished data). Island-wide eradication of rats is not currently possible due to potential negative impacts to the protected fox, endemic deer mouse (Peromyscus maniculatus clementis), and native avian populations.

Supernormal clutches attributed to 2 murrelet pairs competing for a nest site have 
been infrequently found on Anacapa, Santa Barbara, and the Coronado Islands (Murray et al. 1983, Whitworth et al. 2013; CIES unpublished data). However, the frequency of supernormal clutches at Seal Cove, specifically the North Wall area, was unprecedented ( 2 sites with supernormal clutches were also reported in 2017; CIES unpublished data). Establishment of artificial nest sites at Seal Cove and SESCI could have 2 primary benefits of (1) increasing murrelet hatching success by decreasing abandonment caused by intraspecific nest site competition and (2) increasing the number of monitored sites for better determination of hatching success, occupancy, timing of breeding, and population trends.

\section{ACKNOWLEDGMENTS}

Murrelet monitoring by the California Institute of Environmental Studies (CIES) in 2012-2016 and a historical summary of murrelet information at SCI obtained by Humboldt State University (HSU) in 1994-1996 were funded by the U.S. Navy (Commander Pacific Fleet) with key assistance from J. Rice and K. O'Connor. Logistical support at SCI in 2012-2016 was provided by J. Coler. Critical partnering support was provided by the Institute for Wildlife Studies with key assistance from D. Garcelon, D. Johnson, J. Stahl, N. Desnoyers, and D. Biteman. CIES provided most field equipment and key administrative support through the efforts of F. Gress and J. Brenner. Monitoring was assisted by A. Ballent, T. Dvorak, P. Hébert, P. Kelly, J. Koepke, J. Mason, and J. Stahl. Invaluable boat charter support was provided by the Algalita Marine Research Foundation (ORV Alguita) with its excellent captains C. Moore and D. Selvam and crew M. DeFelice and R. deVine.

Funding for HSU surveys in 1994-1996 was provided by the U.S. Navy (Legacy Resources Management Program), California Department of Fish and Wildlife, and U.S. Fish and Wildlife Service, with key assistance from T. Keeney, E. Burkett, and T. Zimmerman. Surveys were assisted by J. Bulger, W. McIver, G. McChesney, L. Ochikubo-Chan, and M. Pierson. Invaluable boat charter support was provided by Instinct Charters (FV Instinct) with its excellent captain D. Christy and first mate B. Christy.

\section{Literature Cited}

BEnT, A.C. 1919. Life histories of North American diving birds. Smithsonian Institution U.S. National Museum Bulletin 107.

BirT, T.P., H.R. Carter, D.L. Whitworth, A. McDonald, S.H. Newman, F. Gress, E. Palacios, J.S. Koepke, and V.L. Friesen. 2012. Rangewide population structure of the Xantus's Murrelet (Synthliboramphus hypoleucus). Auk 129:44-55.

Bridges, A.S., J.N. SancheZ, and D.S. Biteman. 2015. Spatial ecology of invasive feral cats on San Clemente Island; implications for control and management. Journal of Mammalogy 96:81-89.

Briggs, K.T., W.B. Tyler, D.B. Lewis, and D.R. CarLSON. 1987. Bird communities at sea off California: 1975 to 1983. Studies in Avian Biology 11:1-74.

Burkett, E.E., N.A. Rojek, A.E. Henry, M.J. Fluharty, L. Comrack, P.R. Kelly, A.C. Mahaney, and K.M. FIEN. 2003. Status review of Xantus's Murrelet (Synthliboramphus hypoleucus) in California. California Department of Fish and Game, Habitat Conservation Planning Branch, Status Report 2003-01, Sacramento, CA.

Carter, H.R. 2003. Oil and California's seabirds: an overview. Marine Ornithology 31:1-7.

Carter, H.R., S.G. Sealy, E.E. Burkett, and J.F. Piatt. 2005. Biology and conservation of the Xantus's Murrelet: discovery, taxonomy, and distribution. Marine Ornithology 33:81-87.

Carter, H.R., D.L. Whitworth, J.Y. Takekawa, T.W. Keeney, And P.W. Kelly. 2000. At-sea threats to Xantus' Murrelets (Synthliboramphus hypoleucus) in the Southern California Bight. Pages 435-447 in D. Browne, H. Chaney, and K. Mitchell, editors, 5th Channel Islands Symposium. Minerals Management Service, Camarillo, CA.

Cohen, J. 1988. Statistical power analysis for the behavioral sciences. 2nd edition. Lawrence Erlbaum Associates, Hillsdale, NJ. 596 pp.

Cooper, J.G. 1870. The fauna of California and its geographic distribution. Proceedings of the California Academy of Sciences 4:61-81.

Drost, C.A., AND D.B. Lewis. 1995. Xantus' Murrelet (Synthliboramphus hypoleucus). In: A. Poole and F. Gill, editors, The Birds of North America No. 164. The Academy of Natural Sciences, Philadelphia, PA, and American Ornithologists' Union, Washington, DC.

GibBs, J.P., AND E. EnE. 2010. Program Monitor: estimating the statistical power of ecological monitoring programs. Version 11.0.0. www.esf.edu/efb/gibbs/ monitor

Grinnell, J., AND A.H. Miller. 1944. The distribution of the birds of California. Pacific Coast Avifauna 27.

Hamilton, C.D., R.T. Golightly, and J.Y. Takekawa. 2011. Relationships between breeding status, socialcongregation attendance and foraging distance of Xantus's Murrelets. Condor 113:140-149.

Higgins, T.W., A.S. Bridges, and J.N. Sanchez. 2015. Spatial ecology of invasive black rats (Rattus rattus) on San Clemente Island, California. Southwestern Naturalist 60:186-192.

Howell, A.B. 1917. Birds of the islands off the coast of southern California. Pacific Coast Avifauna 12.

Hunt, G.L., R.L. Pitman, And H.L. Jones. 1980. Distribution and abundance of seabirds breeding on California 
Channel Islands. Pages 443-459 in D.W. Power, editor, The California Islands: proceedings of a multidisciplinary symposium. Santa Barbara Museum of Natural History, Santa Barbara, CA.

Hunt, G.L., Jr., R.L. Pitman, M. Naughton, K. Winnett, A. Newman, P.R. Kelly, and K.T. Briggs. 1979. Distribution, status, reproductive biology and foraging habits of breeding seabirds. Pages 1-399 in Summary of marine mammals and seabird surveys of the Southern California Bight area, 1975-1978. Vol. 3. Investigator's reports, Part 3: Seabirds of the Southern California Bight, Book 2. Unpublished report, University of California, Irvine, CA.

[IUCN] INTERNATIONAL UNION FOR CONSERVATION OF NATURE. 2017. The IUCN Red List of Threatened Species. Version 2017-1. www.iucnredlist.org

JEHL, J.R., JR., AND S.I. BoND. 1975. Morphological variation and species limits in the genus Endomychura. Transactions of the San Diego Society of Natural History 18:9-23.

Jorgensen, P.D., AND H.L. Ferguson. 1984. The birds of San Clemente Island. Western Birds 15:111-130.

Karnovsky, N.J., L.B. Spear, H.R. Carter, D.G. Ainley, K.D. AmEY, L.T. Ballance, K.T. BRiggs, R.G. Ford, G.L. Hunt JR., C. Keiper, ET AL. 2005. At-sea distribution, abundance and habitat affinities of Xantus's Murrelets. Marine Ornithology 33:89-104.

KeITT, B.S. 2005. Status of Xantus's Murrelet and its nesting habitat in Baja California, Mexico. Marine Ornithology 33:105-114.

Linton, C.B. 1909. Further notes from San Clemente Island. Condor 11:193-194.

McChesney, G.J., and B.R. Tershy. 1998. History and status of introduced mammals and impacts to breeding seabirds on the California Channel Islands and Northwestern Baja California Islands. Colonial Waterbirds 21:335-347.

Murray, K.G., K. Winnett-Murray, Z.A. Eppley, G.L. HunT JR., AND D.B. SCHWARTZ. 1983. Breeding biology of the Xantus' Murrelet. Condor 85:12-21.

Phillips, R.B., C.S. Winchell, AND R.H. SCHMidT. 2007. Dietary overlap of an alien and native carnivore on San Clemente Island, California. Journal of Mammalogy 88:173-180.

Schwemm, C.A., AND P.L. Martin. 2005. Response of nest success of Xantus's Murrelets (Synthliboramphus hypoleucus) to native predator abundance, Santa Barbara Island, California. Pages 373-384 in D.K. Garcelon and C.A. Schwemm, editors, Proceedings of the Sixth California Islands Symposium. National Park Service Technical Publication CHIS-05-01. Institute for Wildlife Studies, Arcata, CA.

SEALY, S.G. 1974. Breeding phenology and clutch size in the Marbled Murrelet. Auk 91:10-23.

SEALY, S.G. 1976. Biology of nesting Ancient Murrelets. Condor 78:294-306.

[SEMARNAT] Secretaría de Medio Ambiente And Recursos Naturales. 2010. NORMA Oficial Mexicana NOM-059-SEMARNAT-2010, Protección ambiental-Especies nativas de México de flora y fauna silvestres-Categorías de riesgo y especificaciones para su inclusión, exclusión o cambio-Lista de especies en riesgo. Diario Oficial. Jueves 30 de diciembre de 2010. Segunda Sección. Pages 1-78. Norma Oficial.

ShePard, F.P., AND K.O. EMERY. 1941. Submarine topography off the California coast, canyons and tectonic interpretations. Geological Society of America Special Paper 31:1-171.

Sullivan, B.L., E.L. Kerschner, J.J. Dunn, R.S.A. Kaler, S. Lynn, N.M. Munkwitz, AND J.H. Plissner. 2005. The birds of San Clemente Island. Western Birds 36:158-273.

[USFWS] United States Fish and Wildlife Service. 2016. Endangered and threatened wildlife and plants; 12-month findings on petitions to list nine species as endangered or threatened species. Federal Register 81(183):64843-64857.

Whitworth, D.L., AND H.R. CARTER. 2014. Nocturnal spotlight surveys for monitoring Scripps's Murrelets in at-sea congregations at Anacapa Island, California. Monographs of the Western North American Naturalist 7:306-320.

Whitworth, D.L., And H.R. Carter. 2018a. Population trends for Scripps's Murrelet following eradication of black rats. Journal of Wildlife Management 82: 232-237.

Whitworth, D.L., AND H.R. CARTER. 2018b. Scripps's Murrelet at San Miguel Island, California: status of a small population at the northwest limit of the breeding range. Western North American Naturalist 78: $441-456$

Whitworth, D.L., H.R. Carter, T.M. Dvorak, L.S. FARLEY, AND J. KING. 2014. Status, distribution, and conservation of the Scripps's Murrelet at Santa Catalina Island, California. Monographs of the Western North American Naturalist 7:321-338.

Whitworth, D.L., H.R. Carter, and F. Gress. 2013. Recovery of a threatened seabird after eradication of an introduced predator: eight years of progress for the Scripps's Murrelet at Anacapa Island, California. Biological Conservation 162:52-59.

Whitworth, D.L., H.R. Carter, E. Palacios, and F. GREss. 2018. Breeding of Craveri's Murrelet Synthliboramphus craveri at four islands of west-central Baja California, México. Marine Ornithology 46: 117-124.

Whitworth, D.L., H.R. Carter, R.J. Young, J.S. Koepke, F. GRESS, AND S. FANGMAN. 2005. Initial recovery of Xantus's Murrelets following rat eradication on Anacapa Island, California. Marine Ornithology 33: 131-137.

Whitworth, D.L., J.Y. TaKeKaWA, H.R. Carter, and W.R. MCIVER. 1997. Night-lighting as an at-sea capture technique for Xantus' Murrelets in the Southern California Bight. Colonial Waterbirds 20:525-531.

Willett, G. 1912. Birds of the Pacific Slope of southern California. Pacific Coast Avifauna 7.

Winnett, K.A., K.G. MurRaY, And J.C. WingField. 1979. Southern race of Xantus' Murrelet breeding on Santa Barbara Island, California. Western Birds 10: $81-82$.

Wolf, S., C. Phillips, J.A. Zepeda-Dominguez, Y. Albores-Barajas, and P. Martin. 2005. Breeding biology of Xantus's Murrelet at the San Benito Islands, Baja California, Mexico. Marine Ornithology 33:123-129.

Received 24 February 2017

Revised 4 October 2017

Accepted 12 January 2018

Published online 29 October 2018 
Appendix 1, Table 1. Annual capture totals for Scripps's Murrelets and Guadalupe Murrelets at Seal Cove, San Clemente Island, in 1994, 1996, and 2008. The percentage of GUMU in the annual Seal Cove capture total is indicated in parentheses after the number of GUMU banded.

\begin{tabular}{|c|c|c|c|c|}
\hline \multirow[b]{2}{*}{ Year (nights) } & \multicolumn{2}{|c|}{ Scripps's Murrelet } & \multicolumn{2}{|c|}{ Guadalupe Murrelet } \\
\hline & Banded & Breeding & Banded & Breeding \\
\hline $1994(2)$ & $7^{\mathrm{a}}$ & - & $2(29 \%)$ & - \\
\hline $1996(1)$ & 5 & $1(20 \%)$ & $1(20 \%)$ & - \\
\hline $2008(1)$ & 6 & $1(17 \%)$ & $6(50 \%)$ & - \\
\hline TOTAL $(4)$ & 18 & $2(11 \%)$ & $9(33 \%)$ & - \\
\hline
\end{tabular}

aIncluding one bird identified as a scrippsi $\times$ hypoleucus intergrade (Jehl and Bond 1975).

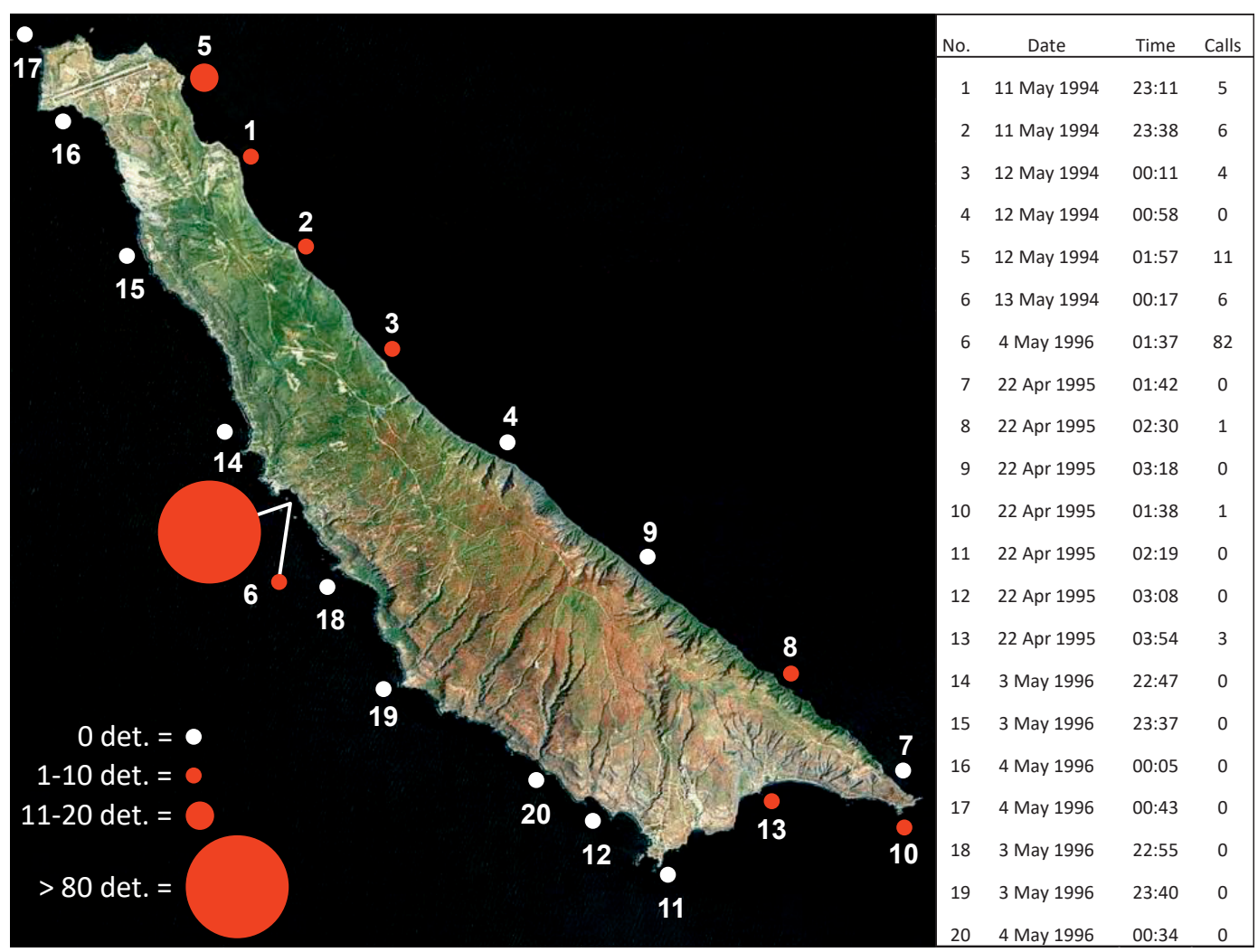

Appendix 1, Fig. 1. Summary of murrelet vocalization surveys at San Clemente Island in 1994-1996. Colored circles indicate the survey locations and are scaled to the number of calls heard during the 15-min surveys. Survey station numbers next to the circles correspond to the data (station number, date, time [PST], and number of calls heard) included in the table to the right. 


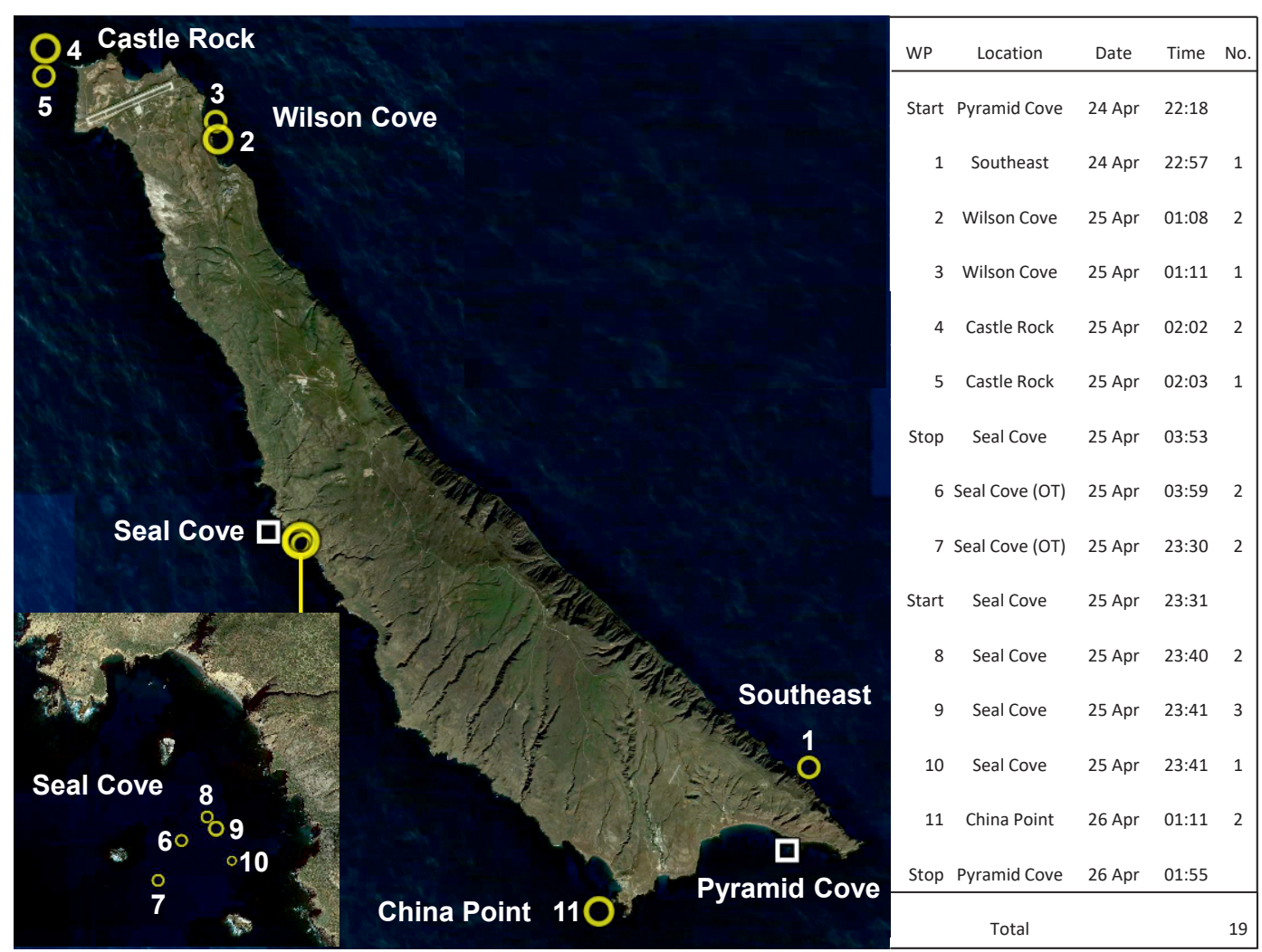

Appendix 1, Fig. 2. Summary of the murrelet round-island spotlight survey conducted at San Clemente Island on nights of 24-25 April 2008. Yellow circles are survey waypoints (WP) scaled to the number of murrelets counted at each location, including any observed off transect (OT). The table includes survey start/stop times and data (WP number, location, date, time [PST], and number of murrelets) for each waypoint. 